\title{
PERAN PERGURUAN TINGGI DALAM MENSOSIALISASIKAN DAMPAK KENAKALAN REMAJA DI SMPN 03 PENITI KABUPATEN SEKADAU
}

\author{
Fusnika, Dessy Triana Relita, Agnesia Hartini, Sarayati \\ STKIP Persada Khatulistiwa Sintang, Jl. Pertamina-Sengkuang-Sintang \\ Email: fusnika804@gmail.com, dssytriana.relita@gmail.com, Agnesiahartini21@yahoo.com, \\ Sarayati39@gmail.com
}

\begin{abstract}
The Role of Universities in socializing the impact of juvenile delinquency as for the objects that were targeted in this service activity were students at 03 Peniti Middle School in Sekadau District. Location of Service in the Village of Peniti is a village located in Sekadau District. The partners involved in this service were students at the 03 Peniti Middle School in Sekadau District who were subjected to counseling about the effects of juvenile delinquency. Their involvement is as a participant who becomes the target object of Extension activities. The age of adolescence is the age at which children seek identity, so through this extension activity can contribute to the impact of juvenile delinquency. Based on the results of the implementation of community service activities it has been carried out properly. The participants of the activity were very enthusiastic and the school provided support and appreciation to STKIP Persada Khatuliswa through the lecturers who carried out counseling activities. In the future the school hopes that they can always cooperate.
\end{abstract}

keywords: College, Juvenile Delinquency, Sekadau Regency

ISSN: $2540-8038$ 


\begin{abstract}
Abstrak
Peran Perguruan Tinggi Dalam mensosialisasikan dampak kenakalan remaja adapun objek yang menjadi sasaran dalam kegiatan pengabdian ini adalah pelajar di SMPN 03 Peniti Kabupaten Sekadau. Lokasi Pengabdian di Desa Peniti merupakan sebuah desa yang terletak di Kabupaten Sekadau. Mitra yang terlibat pada pengabdian ini adalah para pelajar di SMPN 03 Peniti Kabupaten Sekadau yang mengalami sasaran dalam penyuluhan tentang dampak kenakalan remaja. Keterlibatan mereka adalah sebagai peserta yang menjadi objek sasaran dari kegiatan Penyuluhan. Usia remaja adalah usia di mana anak mencari jati diri oleh karena itu melalui kegiatan penyuluhan ini dapat memberikan kontribusi tentang dampak kenakalan remaja. Berdasarkan hasil pelaksanaan kegiatan Pengabdian kepada masyarakat telah dilaksanakan dengan baik. Peserta kegiatan sangat antusias dan pihak sekolah memberikan dukungan serta apresiasi kepada STKIP Persada Khatuliswa melalui pihak dosen yang melakukan kegiatan penyuluhan. Kedepannya pihak sekolah mengaharapkan agar dapat selalu berkerjasama.
\end{abstract}

Kata Kunci: Perguruan Tinggi, Kenakalan Remaja,Kabupaten Sekadau 


\section{A. Pendahuluan}

Usia remaja adalah usia di mana anak mencari jati diri, banyak perilaku yang didasarkan untuk cobacoba. yang dilakukan oleh anak usia remaja yang sering disebut kenakalan remaja (juvenille delinquency). Kenakalan remaja banyak sekali jenisnya. antara lain adalah penyalahgunaan narkoba, seks bebas, tawuran antar pelajar dan lain-lain.

Remaja merupakan aset masa depan suatu bangsa. Hal tersebut adalah merupakan suatu masalah yang dihadapi masyarakat. Oleh karena itu masalah kenakalan remaja seyogyanya mendapatkan perhatian yang serius dan terfokus untuk mengarahkan remaja ke arah yang lebih positif, untuk terciptanya suatu sistem dalam menanggulangi kenakalan di kalangan remaja.

\section{Data Komnas Perlindungan}

Anak merilis jumlah tawuran pelajar tahun ini sebanyak 339 kasus dan memakan korban jiwa 82 orang. Tahun sebelumnya, jumlah tawuran antar-pelajar sebanyak 128 kasus (http://megapolitan.kompas.com).

Terhitung ada 4 peristiwa tawuran yang terjadi April sampai dengan
Oktober 2011 yang melibatkan pelajar SMA dan SMK di 8 sekolah. Tidak sedikit pula responden atau keluarga responden yang mengaku pada masa bersekolah terlibat tawuran atau perkelahian massal pelajar. Jumlahnya mencapai 6,6 persen atau sekitar 29 responden (http://megapolitan.kompas.com).

Salah satu solusi yang dapat diberikan adalah memberikan Penyuluhan menumbuhkan dampak kenalakan remaja di kalangan pelajar SMPN 03 Peniti Kecamatan Sekadau.

\section{B. Metode}

Dalam pelaksanaannya program penyuluhan ini direncanakan dilaksanakan melalui 2 (dua) langkah atau tahapan kegiatan sebagai berikut:

1) Tahap Perencanaan

Adalah tahap pemantapan rencana pelaksanaan kegiatan penyuluhan, pada tahapan ini tim dan peserta menyepakati teknis dan tempat pelaksanaan penyul uhan termasuk mengenai kepastian waktu dan lamanya kegiatan yang dimaksud.

2) Tahap Pelaksanaan 
Pada tahapan ini dilaksanakannya kegiatan penyuluhan: Meningkatkan Kegiatan pengabdian dosen berjudul "Peran Perguruan Tinggi Dalam Mensosialisasikan Dampak Kenakalan Remaja Di SMP Negeri 03 Peniti Kabupaten Sekadau", dilakukan dengan acara tatap muka yang diselenggarakan di SMP Negeri 03 Peniti. Pertemuan ini dihadiri oleh 75 orang siswa. keasadaran para pelajar untuk upaya pencegahan kenakalan remaja, meningkatkan kesadaran para pelajar akan dampak yang ditimbulkan sebagai akibat kenakalan remaja.

\section{Pembahasan dan Hasil}

\section{Pembahasan}

\section{a. Pengertian Kenakalan}

\section{Remaja}

Kenakalan remaja merupakan tingkah laku yang yang melampaui batas toleransi orang lain atau lingkungan sekitar serta suatu tindakan yang dapat melanggar norma-norma dan hukum. Secara sosial kenakalan remaja ini dapat disebabkan oleh suatu bentuk pengabaian sosial sehingga remaja ini dapat mengembangkan bentuk perilaku yang menyimpang.

Sumiati (2009), mendefinisikan kenakalan remaja adalah suatu perilaku yang dilakukan oleh remaja dengan mengabaikan nilai-nilai sosial yang berlaku di dalam masyarakat. Kenakalan remaja meliputi semua perilaku yang menyimpang dari norma-norma dan hukum yang dilakukan oleh remaja. Perilaku ini dapat merugikan dirinya sendiri dan orang-orang sekitarnya. Hurlock (1999), menyatakan kenakalan remaja adalah tindakan pelanggaran hukum yang dilakukan oleh remaja, dimana tindakan tersebut dapat membuat seseorang atau remaja yang melakukannya masuk kedalam penjara.

Menurut Gunarsa (2004), mendefinisikan kenakalan remaja itu terjadi pada remaja yang mempunyai konsep diri lebih negatif dibandingkan dengan remaja yang tidak bermasalah. 
Remaja yang dibesarkan dalam keluarga kurang harmonis dan memiliki kecenderungan yang lebih besar menjadi remaja yang nakal dibandingkan remaja yang dibesarkan dalam keluarga harmonis dan memiliki konsep diri yang positif. Berdasarkan beberapa pendapat dari para tokoh diatas, jadi yang dimaksud dengan kenakalan remaja adalah kecenderungan remaja untuk melakukan tindakan yang melanggar aturan yang dapat mengakibatkan kerugian dan kerusakan baik terhadap dirinya sendiri maupun orang lain.

Kartono (2003), mengatakan bahwa remaja nakal mempunyai karakteristik umum yang sangat berbeda dengan remaja yang tidak nakal, perbedaan kenakalan remaja itu melingkupi :

a) Struktur intelektual. Fungsifungsi kognitif pada remaja yang nakal akan mendapatkan nilai lebih tinggi untuk tugastugas prestasi daripada nilai untuk keterampilan verbal. Remaja yang nakal kurang toleran terhadap hal-hal yang ambisius dan kurang mampu memperhitungkan tingkah laku orang lain serta menganggap orang lain sebagai cerminan dari diri sendiri.

b) Fisik dan psikis. Remaja yang nakal lebih "idiot secara moral" dan memiliki karekteristik yang berbeda secara jasmaniah (fisik) sejak lahir jika dibandingkan remaja yang normal. Bentuk tubuhnya lebih kekar, berotot, kuat, dan bersikap lebih agresif.

Fungsi fisiologis dan dan neurologisyang khas pada remaja nakal adalah kurang bereaksi terhadap stimulus kesakitan dan menunjukkan ketidakmatangan jasmaniah.

c) Karakteristik individual. Remaja yang nakal mempunyai sifat kepribadian khusus yang menyimpang, seperti : berorientasi pada masa sekarang, bersenang-senang dan puas pada hari ini tanpa memikirkan masa depan; terganggu secara emosional; kurang bersosialisasi dengan 
masyarakat normal, sehingga tidak mampu mengenal normanorma kesusilaan, dan tidak bertanggung jawab secara sosial; sangat impulsif, suka tantangan serta bahaya; dan kurang memiliki disiplin diri serta kontrol diri.

Remaja nakal adalah remaja yang berbeda dari remaja biasa. Remaja yang nakal lebih percaya diri, mempunyai kontrol diri yang kurang, tidak mempunyai orientasi pada masa depan, dan kurang dalam kematangan sosial, sehingga sulit menyesuaikan diri dengan lingkungan sosial.

\section{b. Jenis Kenakalan Remaja}

Menurut Gunarsa (2004), bentuk-bentuk kenakalan remaja dibagi menjadi dua, yaitu :

a) Kenakalan yang bersifat amoral dan asosial yang tidak diatur dalam undang-undang, sehingga sulit digolongkan sebagai pelanggaran hukum,

b) Kenakalan yang bersifat melanggar hukum dengan penyelesaiannya sesuai dengan undang-undang dan hukum yang berlaku sama dengan perbuatan hukum bila dilakukan pada orang dewasa.

$$
\text { Sunarwiyati }
$$
membagi bentuk kenakalan remaja menjadi : Kenakalan biasa, seperti: suka berkelahi, suka keluyuran, membolos sekolah, pergi dari rumah tanpa pamit, berkelahi dengan teman dan berkeluyuran, Kenakalan yang menjurus pada pelanggaran dan kejahatan, seperti mengendarai mobil tanpa SIM, mengambil barang tua tanpa ijin, mencuri, dan kebut-kebutan. Kenakalan khusus, seperti penyalahgunaan narkoba, hubungan seks diluar nikah, pemerkosaan, aborsi, dan pembunuhan.

Menurut Kartono (2003), bentuk-bentuk perilaku kenakalan remaja dibagi menjadi empat, yaitu: Kenakalan Remaja Terisolir (Delinkuensi Terisolir)

\section{c. Faktor Penyebab Terjadinya Kenaklana Remaja Papalia (2004), mengatakan} bahwa remaja yang kurang diawasi, 
dijaga, diberi bimbingan dan diperhatikan oleh orangtuanya terlebih ibu maka akan cenderung berperilaku memberontak atau melakukan tindakan tindakan yang menyimpang dari norma-norma yang berlaku dimasyarakat.

$$
\text { Gunarsa }
$$

mengelompokkan faktor-faktor penyebab kenakalan remaja menjadi

Faktor pribadi : setiap anak memiliki kepribadian khusus, dan keadaan khusus pada anak ini dapat menjadi sumber munculnya perilaku menyimpang. Keadaan khusus ini adalah keadaan konstitusi yaitu potensi bakat atau sifat dasar pada anak yang kemudian melalui proses perkembangan, kematangan atau perangsangan dari lingkungan menjadi aktual, muncul dan berfungsi .

Faktor keluarga: keluarga mempunyai peranan yang besar terhadap perkembangan sosial pada anak. Keluarga secara langsung atau tidak langsung akan berhubungan terus menerus dengan anak, memberikan rangsangan melalui berbagai corak komunikasi antara orangtua dengan anak, hubungan antar pribadi dalam keluarga yang meliputi pula hubungan antar saudara menjadi faktor yang penting terhadap munculnya perilaku yang tergolong nakal. Struktur tanggung jawab dalam sebuah keluarga secara umum bahwa ayah bertugas mencari nafkah, sedangkan ibu bertugas merawat rumah dan mendidik anakanak, sehingga fungsi ibu dalam proses pengasuhan dan pendidikan terhadap anak sangat penting. Fungsi ibu tersebut dapat mengalami hambatan jika ibu keluar dari jalur tanggung jawabnya, seperti ikut bekerja di luar rumah, sehingga pengasuhan dan pendidikan terhadap anak bisa jadi kurang maksimal.

Lingkungan sosial dan dinamika perubahannya : Perubahan yang terjadi di dalam masyarakat memunculkan ketidakserasian dan ketegangan yang berdampak pada sikap dan lingkungan pergaulan. Perubahan jaman yang begitu cepat dan arus informasi yang tidak terkontrol akan membuat seseorang mudah terpengaruh serta lingkungan yang negatif akan menjerumuskan 
anak pada perilaku nakal.

Faktor-faktor kenakalan remaja menurut Kartono (1985) adalah: kurangnya kasih sayang orang tua, kurangnya pengawasan dari orang tua, pergaulan dengan teman yang tidak sebaya, peran dari perkembangan iptek yang berdampak negatif, tidak adanya bimbingan kepribadian dari sekolah, dasar-dasar agama yang kurang, tidak adanyamedia penyalur bakat dan hobinya, kebebasan yang berlebihan, serta adanya masalah yang dipendam.

\section{d. Akibat Kenakalan Remaja} Dari Segi Hukum

Menurut Haryanto (2011), dampak atau akibat dari perilaku kenakalan remaja antara lain: Kenakalan dalam keluarga, remaja yang labil umumnya rawan sekali melakukan hal-hal yang negatif, di sinilah peran orang tua. Orang tua harus mengontrol dan mengawasi putra-putri mereka dengan melarang hal-hal tertentu. Namun, bagi sebagian anak remaja, laranganlarangan tersebut malah dianggap hal yang buruk dan mengekang mereka. Akibatnya, mereka akan memberontak dengan banyak cara. Tidak menghormati, berbicara kasar pada orang tua, atau mengabaikan perkataan orang tua adalah contoh kenakalan remaja dalam keluarga. Kenakalan dalam pergaulan, dampak kenakalan remaja yang paling nampak adalah dalam hal pergaulan. Sampai saat ini, masih banyak para remaja yang terjebak dalam pergaulan yang tidak baik. Mulai dari pemakaian obat-obatan terlarang sampai seks bebas. Menyeret remaja pada sebuah pergaulan buruk memang relatif mudah, dimana remaja sangat mudah dipengaruhi oleh hal-hal negatif yang menawarkan kenyamanan semu. Akibat pergaulan bebas inilah remaja, bahkan keluarganya, harus menanggung beban yang cukup berat.

Kenakalan dalam pendidikan: Kenakalan dalam bidang pendidikan memang sudah umum terjadi, namun tidak semua remaja yang nakal dalam hal pendidikan akan menjadi sosok yang berkepribadian buruk, karena mereka masih cukup mudah untuk 
diarahkan pada hal yang benar. Kenakalan dalam hal pendidikan misalnya, membolos sekolah, tidak mau mendengarkan guru, tidur dalam kelas dan lain-lain.

Dampak kenakalan remaja pasti akan berimbas pada remaja tersebut. Bila tidak segera ditangani, ia akan tumbuh menjadi sosok yang bekepribadian buruk.

Remaja yang melakukan kenakalan-kenakalan tertentu pastinya akan dihindari atau malah dikucilkan oleh banyak orang. Remaja tersebut hanya akan dianggap sebagai pengganggu dan orang yang tidak berguna. Akibat dari dikucilkannya ia dari pergaulan sekitar, remaja tersebut bisa mengalami gangguan kejiwaan. Gangguan kejiwaan bukan berarti gila, tapi ia akan merasa terkucilkan dalam hal sosialisai, merasa sangat sedih, atau malah akan membenci orang-orang sekitarnya.

Dampak kenakalan remaja yang terjadi, tak sedikit keluarga yang harus menanggung malu. Hal ini tentu sangat merugikan, dan biasanya anak remaja yang sudah terjebak kenakalan remaja tidak akan menyadari tentang beban keluarganya. Masa depan yang suram dan tidak menentu bisa menunggu para remaja yang melakukan kenakalan. Bayangkan bila ada seorang remaja yang kemudian terpengaruh pergaulan bebas, hampir bisa dipastikan dia tidak akan memiliki masa depan cerah. Hidupnya akan hancur perlahan dan tidak sempat memperbaikinya.

Kriminalitas bisa menjadi salah satu dampak kenakalan. Remaja yang terjebak hal-hal negatif bukan tidak mungkin akan memiliki keberanian untuk melakukan tindak kriminal. Mencuri demi uang atau merampok untuk mendapatkan barang berharga.

Ketika seorang remaja sudah melakukan perbuatan kriminal artinya sudah melakukan perbuatan pidana. Erbuatan pidana yang dilakukan akan berdampak pada penjatuhan sanksi pidannaya. penjatuhan pidana sebagai upaya pembinaan dan perlindungan anak merupakan faktor penting. Salah satu upaya pemerintah bersama DPR adalah terbitnya Undang- 
Undang RI Nomor 3 Tahun 1997 tentang Pengadilan Anak. Undangundang ini diundangkan pada tanggal 3 Januari 1997 (Lembaran Negara 1997 Nomor 3, Tambahan Lembaran Negara Nomor 3668) dan mulai diberlakukan satu tahun kemudian yaitu tanggal 3 Januari 1998. Melalui Undang-undang No. 3 Tahun 1997 diatur perlakuan khusus terhadap anak nakal, yang berbeda dengan pelaku tindak pidana orang dewasa. Misalnya ancaman pidana $1 / 2$ (satu perdua) dari ancaman maksimum pidana bagi orang dewasa, tidak dikenal pidana penjara seumur hidup ataupun pidana mati. Hal ini bukan berarti menyimpang dari prinsip equality before the law. Ketentuan demikain dalam rangka menjamin pertumbuhan dan perkembangan fisik, mental dan sosial secara utuh, serasi, selaras dan seimbang bagi anak. Sebelum lahir Undangundang No 3 Tahun 1997, pada tahun 1979 telah ada undangundang yang mengatur mengenai kesejahteraan anak, yaitu Undangundang Nomor 4 Tahun 1979. e. Upaya Pencegahan Dari Kenakalan Remaja

Upaya Preventif adalah
kegiatan yang dilakukan secara
sistematis terarah dan terencana, untuk menjaga agar kenakalan anak tersebut tidak timbul. Uapay peventif lebih besar manfaatnya daripada upaya kuratif, karena jika kenakalan tersebut telah meluas, maka amat sulit menanggulanginya. Berbagai upaya preventatif dapat dilakukan, akan tetapi secara garis besarnya dapat dikelompokkan atas tiga bagian: Keluarga atau di rumah tangga. Orang tua menciptakan kehidupan rumah tangga yang beragama, artinya membuat suasana rumah tangga atau keluarga menjadi kehidupan yang taat dan taqwa kepada Allah didalam kehidupan sehari-hari. Menciptakan keluarga yang harmonis, artinya dimana hubungan ayah, ibu dan anak tidak terdapat percekcokan atau pertentang. Hal ini dapat dilakukan dengan memberikan waktu terluang untuk berkumpul bersama anak-anak misalnya makan bersama. Diwaktu makan bersama itu sering keluar ucapan-ucapan atau keluhan anak 
secara spontan. Spontanitas itu amat penting bagi orang tua sebagai bahan pertimbangan untuk memahami diri anak-anaknya.

Adanya kesamaan normanorma yang dipegang antara ayah, ibu dan keluarga lainnya di rumah tangga dalam mendidik anak-anak. Memberikan kasih sayang secara wajar kepada anak-anak, artinya kasih sayang yang wajar bukanlah dalam rupa materi berlebihan, akan tetapi dalam bentuk hubungan psikologis dimana orang tua dapat memahami perasaan anaknya dan mampu mengantisipasinya dengan cara-cara edukatif.

Memberikan perhatian yang memadai terhadap kebutuhan anak. Memberikan perhatian kepada anak berarti menumbuhkan kewibawaan pada orang tua dan kewibawaan akan menimbulkan sikap kepenurutan yang wajar kepada anak didik. Memberikan pengawasan secara wajar terhadap pergaulan anak remaja di lingkungan masyarakat. Hal-hal yang perlu diawasi adalah teman- teman bergaulnya, disiplin waktu, pemakaian uang dan ketaatan melakukan ibadah kepada Tuhan.
Upaya di Sekolah, Guru hendaknya memahami aspek-aspek psikis murid. Untuk hal tersebut guru sebaiknya memiliki ilmu-ilmu tertentu antara lain: psikologi perkembangan, bimbingan dan konseling serta ilmu mengajar (didaktik-metodik). Dengan adanya ilmu-ilmu tersebut maka teknik pemahaman individu murid akan lebih obyektif sehingga memudahkan guru memberikan bantuan kepada murid-muridnya.

Mengintensifkan pelajaran agama dan mengadakan tenaga guru agama yang ahli dan berwibawa serta mampu bergaul secara harmonis dengan guru-guru umum lainnya. Adapun hal yang perlu diperhatikan guru dalam memberikan pendidikan agama antara lain: Memperhatikan perkembangan jiwa anak, Memberikan keterampilan yang sesuai dengan ajaran agama.

Memperhatiakan suasana pergaulan anak diluar,Mengintensifkan bagian bimbingan dan konseling di sekolah dengan cara mengadakan tenaga ahli atau menatar guru-guru untuk mengelola bagian ini. Adanya 
kesamaan norma-norma yang gurulah yang memegang segala dipegang oleh guru-guru. Hal ini tanggung jawab soal pendidikan. akan menimbulkan kekompakan Pendapat seperti ini perlu dikoreksi. dalam membimbing murid-murid. Karena apalah artinya pendidikan Adanya kekompakan itu akan menimbulkan kewibawaan guru yang diberikan di sekolah dan di rumah jika di masyarakat.

dimata murid-murid, dan sekaligus memperkecil timbulnya kenakalan.

Melengkapi fasilitas sekolah. seperti: gedung, laboratorium, masjid, alat-alat pelajaran, alat-alat olah raga dan kesenian, alat-alat keterampilan dan sebagainya. Dengan lengkapnya fasilitas tersebut akan dapat digunakan untuk mengisi waktu luang misalnya selama libur sekolah. Disamping itu dapat pula mengembangkan bakat murid

Upaya di Masyarakat adalah tempat pendidikan ketiga sesudah rumah dan sekolah. Ketiganya haruslah mempunyai keseragaman dalam mengarahkan anak untuk tercapainya tujuan pendidikan. Apabila salah satu pincang maka yang lain akan mengalami kepincang pula. Pendidikan di masyarakat biasanya diabaikan orang. Karena banyak orang yang berpendapat bahwa jika anak telah di sekolahkan berarti semuanya sudah beres dan

\section{Simpulan}

Berdasarkan hasil pelaksanaan kegiatan Pengabdian kepada Masyarakat, maka dapat disimpulkan bahwa kegiatan yang bertema "Peran Perguruan Tinggi Dalam Mensosialisasikan Dampak Kenakalan Remaja Di SMP Negeri 03 Peniti Kabupaten Sekadau" telah dilaksanakan dengan baik. Peserta kegiatan sangat antusias dan pihak sekolah memberikan dukungan serta apresiasi kepada pihak STKIP Persada Khatuliswa melalui pihak dosen yang melakukan kegiatan PKm ini. Kedepannya pihak sekolah mengaharapkan agar dapat selalu berkerjasama dalam memberikan peyuluhan kepada siswa/i SMP Negeri 3 Peniti.

\section{Daftar Pustaka}

Bimo Walgito, K. 2002. Psikologi Sosial. Yogyakarta: Yayasan Penerbitan Fakultas Psikologi 
Jurnal PEKAN Vol. 4 No. 1 Edisi April 2019 Fusnika \& Dessy.T.R,dkk, Peran ....101

Kamus Besar Bahasa Indonesia. http://www.kamusbesar.com.

Diunduh pada hari Selasa tanggal 13 Oktober 2018, pukul 12.50 WIB.

Soerjono Soekanto. 2003. Sosiologi Suatu Pengantar. Jakarta: PT Raja Grafindo Persada.

Suharjana. 2011. Pendidikan Karakter dalam Perspektif Teori dan Praktik. Yogyakarta: UNY Press.

http://belajarpsikologi.com/kenakala n-remaja/ (2011). Kenakalan remaja. Diunduh pada hari Senin, tanggal 13 Oktober 2018, pukul 12.50 WIB.

Kamus Besar Bahasa Indonesia. http://www.kamusbesar.com. Diunduh pada hari Selasa tanggal 13 Oktober 2018, pukul 12.50 WIB. 